\title{
STEREOSELECTIVE SYNTHESES OF (+)- ISORETRONECANOL AND (+)-5-epi-TASHIROMINE VIA ADDITION OF CHIRAL TITANIUM (IV) ENOLATES TO CYCLIC $N$-ACYLIMINIUM IONS
}

Elaine Pereira, Conceição de Fátima Alves, Maria Alice Böckelmann and Ronaldo A. Pilli*

Instituto de Química, Universidade Estadual de Campinas, CP 6154, 13084-971 Campinas-SP, Brazil

Recebido em 4/1/08; aceito em 14/3/08; publicado na web em 9/4/08

\begin{abstract}
The stereoselective addition of the titanium (IV) enolates derived from (S)-4-isopropyl- $N$-4-chlorobutyryl-1,3-thiazolidine-2-thione (8) and from (S)-4-isopropyl- $N$-4-chloropentanoyl-1,3-thiazolidine-2-thione (9) to $N$-Boc-2-methoxypyrrolidine (5b) afforded the addition products (+)-10 and (+)-11 in 84\% yield in both cases, as 8.6:1 and 10:1 diastereoisomeric mixtures, respectively. A threestep sequence allowed to convert these adducts to (+)-isoretronecanol (1) and (+)-5-epi-tashiromine (2) in $43 \%$ and $49 \%$ overall yield, respectively.
\end{abstract}

Keywords: (+)-isoretronecanol; (+)-5-epi-tashiromine; asymmetric synthesis.

\section{INTRODUCTION}

Pyrrolizidine alkaloids are structurally characterized by the presence of the 1-aza-bicyclo[3.3.0] octane ring system and are widely displayed in Nature being particularly ubiquitous in the genus Senecio (Compositae) where they occur mainly as esters or macrolactones of a necic base and a monocarboxylic or dicarboxylic acids. They may function as insect anti-feedants and are sequestered by some insects as part of their chemical defense weaponry. They represent probably the most common poisonous plants affecting livestock, wildlife and humans. ${ }^{1}$

Indolizidine alkaloids features the 1-aza-bicyclo[4.3.0]nonane ring system and have been isolated from several natural sources, including animals and plants. ${ }^{2}$ They display a variety of biological activities such as insecticidal, fungicidal and antibacterial activities and include some well known natural products such as castanospermine, gephyrotoxin, pumiliotoxins, allopumiliotoxins, securinine and indolizomycin, among others.

These alkaloids have become popular synthetic targets and have served as the testing ground to demonstrate the usefulness of synthetic methodologies, including those based on the use of $\mathrm{N}$ acyliminium ions as the electrophilic species. ${ }^{3}$

In the past, we have explored the addition of carbon nucleophiles such as allyltrimethylsilane, silyloxydienes and boron enolates derived from chiral $\mathrm{N}$-acyl-1,3-oxazolidin-2-ones to chiral $\mathrm{N}$-acyliminium ion precursors to develop efficient approaches to enantiomerically pure pyrrolizidine, indolizidine and quinolizidine alkaloids. ${ }^{4}$

This last approach, which attracted our interest due to the possibility to carry out chirality transfer from the chiral $\mathrm{N}$-acyl1,3-oxazolidin-2-one precursors to achiral $\mathrm{N}$-acyliminium ions, followed by the recovery of the chiral auxiliary, was pioneered by Fuentes et al. who described the addition of chiral 1,3-oxazolidin2-ones to cyclic acylimines ${ }^{5}$ and Nagao and coworkers ${ }^{6}$ who reported on the addition of tin(II) enolates of chiral thiazolidine-2-thiones to $\mathrm{N}$-acylimines and $\mathrm{N}$-acyliminium ions which led to the total synthesis of the pyrrolizidine necine base (-)-supinidine. ${ }^{7}$ We have also described the addition of boron and titanium (IV) enolates derived from chiral $\mathrm{N}$-acyl-1,3-oxazolidin-2-ones to 5- and 6membered $N$-acyliminium ions. ${ }^{8}$

*e-mail: pilli@iqm.unicamp.br
Isoretronecanol (1), a pyrrolizidine alkaloid which is found in Nature in both enantiomeric forms, has been isolated from Planchonella, Hammarbya, Phalaenopsis and Heliotropium species, and it has been synthesized in optically pure form several times in the past. ${ }^{9}$ Among the indolizidine alkaloids, (+/-)-tashiromine and its epimer (+/-)-5-epi-tashiromine (2) have been prepared on several occasions but only a few reports on the synthesis of these alkaloids in enantiomerically pure form appeared (Figure 1). ${ }^{10}$<smiles>OC[C@@H]1CCCN2CCC[C@H]12</smiles>

Isoretronecanol (1), $\mathrm{n}=0$

5-epi-Tashiromine (2), $\mathrm{n}=1$

\section{Figure 1}

Recently, we have disclosed our results on the stereoselective addition of the preformed titanium (IV) enolate derived from $\mathrm{N}-4$ chlorobutyryl-1,3-thiazolidine-2-thione to $\mathrm{N}$-Boc-2-methoxypyrrolidine which allowed the preparation of the pyrrolizidine alkaloid (+)-isoretronecanol (1) in four steps and $36 \%$ overall yield ${ }^{11}$ and herein we describe details of our work and extend this methodology to the synthesis of (+)-5-epi-tashiromine (2), an indolizidine alkaloid which was initially isolated from Maackia tashiroi $^{12}$ and recently from Crotalaria species. ${ }^{13}$

\section{RESULTS AND DISCUSSION}

Our approach initially focused on the addition of the titanium (IV) enolates derived from $N$-chlorobutyryl and $N$-chloropentanoyl1,3-oxazolidin-2-ones (3 and $\mathbf{4}$, respectively) to $N$-tertbutoxycarbonyl-2-ethoxypyrrolidine (5a). The titanium(IV) enolates were generated by treatment of a cooled $\left(0{ }^{\circ} \mathrm{C}\right) \mathrm{CH}_{2} \mathrm{Cl}_{2}$ soln. of oxazolidinones $\mathbf{3}$ and $\mathbf{4}$ with $\mathrm{TiCl}_{4}$ to produce a deeply colored reddish brown soln. of the corresponding enolate which was treated with a $\mathrm{CH}_{2} \mathrm{Cl}_{2}$ soln. of $\mathbf{5 a}$ at $-23{ }^{\circ} \mathrm{C}$ to afford the corresponding adducts in good yields ( 82 and $81 \%$ yield, respectively) as a single diastereoisomer, as determined by ${ }^{1} \mathrm{H}-\mathrm{NMR}$ analyses of the crude 
reaction mixture (Scheme 1). The absolute configuration of the newly formed stereogenic centers in adducts (+)-6 and (+)-7 was determined to be $\left(2 R, 2^{\prime} R\right)$ after X-ray diffraction analysis of a monocrystal of adduct (-)-7. ${ }^{14}$

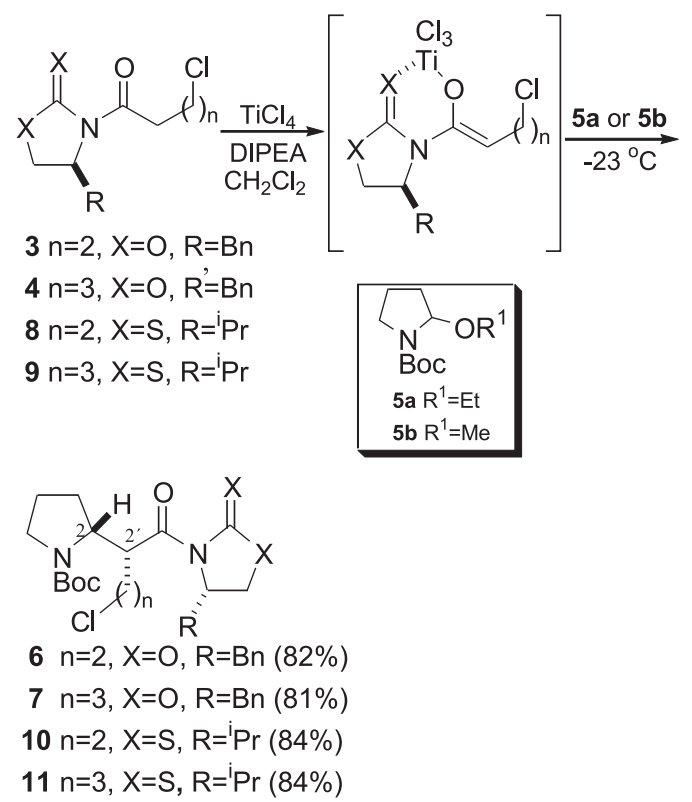

Scheme 1

The stereochemical outcome favoring the $\left(2 R, 2^{\prime} R\right)$ configuration in 6 and 7 may be rationalized via the interaction between the sterically less encumbered $S i$ face of the Z-configured and internally chelated titanium(IV) enolate derived from $\mathbf{3}$ and $\mathbf{4}$ and $\mathrm{Si}$ face of the $\mathrm{N}$-acyliminium ion formed in situ upon addition of $\mathrm{N}$-Boc-2methoxy pyrrolidine (5a) to the red colored $\mathrm{CH}_{2} \mathrm{Cl}_{2}$ solution of the enolate (Figure 2).

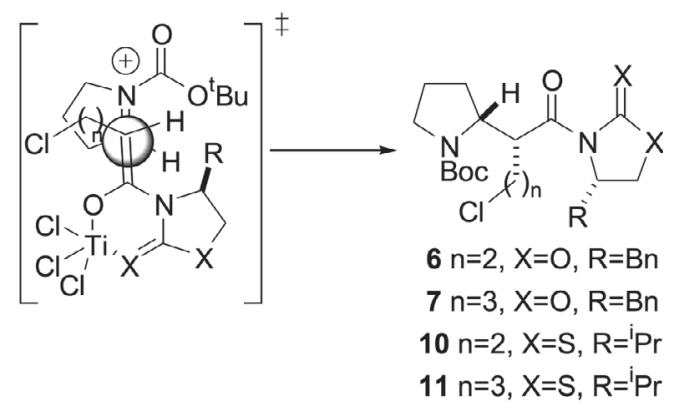

Figure 2

Despite the efficiency of the above process which provided good yield and stereocontrol in the preparation of 2-substituted pyrrolidines, removal of the chiral auxiliary under mild reaction conditions (such as $\mathrm{LiOH} / \mathrm{H}_{2} \mathrm{O}_{2} / \mathrm{THF}, \mathrm{LiBH}_{4} / \mathrm{MeOH}$ or $\mathrm{PhCH}_{2} \mathrm{SLi} /$ $\mathrm{THF}$ ) proved to be difficult as low yields of the corresponding carboxylic acid, alcohol or thioester were observed due to the competitive attack at the endocyclic carbonyl. ${ }^{15}$

In order to circumvent this problem, we investigated the reaction of the titanium(IV) enolate derived from $N$-chlorobutyryl and $N$ chloropentanoyl-1,3-thiazolidin-2-thiones ( 8 and $\mathbf{9}$, respectively) with $N$-tert-butoxycarbonyl-2-methoxypyrrolidine (5b) as the cleavage of the exocyclic $N$-acyl bond in the $N$-acyl-1,3-thiazolidine2-thiones is favored when compared to the corresponding $\mathrm{N}$-acyl1,3-oxazolidine-2-ones. ${ }^{16}$
Upon treatment of a yellow solution of $N$-chlorobutyryl- and $\mathrm{N}$-chloropentanoyl-1,3-thiazolidin-2-thiones (8 and $\mathbf{9}$, respectively) in $\mathrm{CH}_{2} \mathrm{Cl}_{2}$ with 1.1 equiv. of $\mathrm{TiCl}_{4}$ at $0{ }^{\circ} \mathrm{C}$, followed by addition of 1.1 equiv. of diisopropylethylamine, a redish brown color developed. After addition of a pre-cooled $\mathrm{CH}_{2} \mathrm{Cl}_{2}$ solution of $\mathrm{N}$-Boc-2methoxypyrrolidine $(\mathbf{5 b})$ at $-23{ }^{\circ} \mathrm{C}$, the corresponding adducts $\mathbf{1 0}$ and 11 were isolated in $84 \%$ yield in both cases, after column chromatography in silica gel, as a 8.6:1 and 10:1 diastereoisomeric ratio, respectively, as determined by HPLC analyses on the crude mixture. ${ }^{17}$ These adducts were fully characterized by HRMS, IR, ${ }^{1} \mathrm{H}$ - and ${ }^{13} \mathrm{C}$-NMR spectroscopies, as well as specific optical rotation.

The configuration of the newly generated stereogenic centers in adducts $\mathbf{6}$ and $\mathbf{1 0}$ were shown to be identical after their conversion to the same alcohol 12 upon treatment with $\mathrm{NaBH}_{4}$. The same identity was observed for adducts $\mathbf{7}$ and $\mathbf{1 1}$ which afforded alcohol 13 after reductive cleavage under the same experimental conditions. Their absolute configurations were tentatively assigned based on our previous work ${ }^{8}$ and were eventually confirmed after their conversion to the pyrrolizidine alkaloid (+)-isoretronecanol (1) and to the indolizidine alkaloid (+)-5-epi-tashiromine (2), as depicted below.

Upon treatment of 2-substituted pyrrolidines $\mathbf{1 0}$ and $\mathbf{1 1}$ with $\mathrm{LiBH}_{4}$ in THF/MeOH, an inseparable mixture of alcohols $\mathbf{1 2}$ and 13, respectively, and ( $S$ )-isopropyl-1,3-thiazolidine-2-thione was formed (Scheme 2). Their separation proved not to be necessary at this step as deprotection of the nitrogen with trifluoroacetic acid, followed by addition of an excess of saturated $\mathrm{NaHCO}_{3}$, provided (+)-isoretronecanol (1) and 5-epi-tashiromine (2), in 43 and 49\% overall yield, respectively, after silica gel chromatography. The chiral auxiliary was recovered in 66 and $70 \%$ yield, respectively.

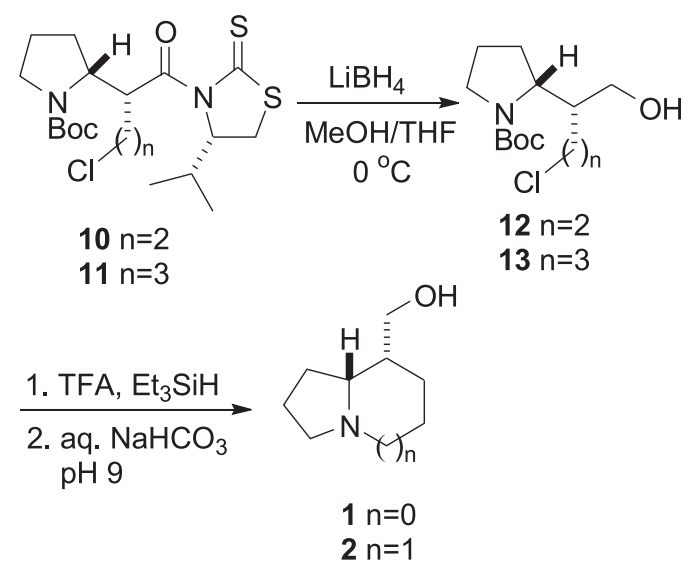

Scheme 2

Synthetic (+)-isoretronecanol (1) and (+)-5-epi-tashiromine (2) were characterized by comparison of their spectroscopic and optical rotation data with those described in the literature..$^{10,18}$ The route described above compares favourably (4 steps and $32 \%$ and $37 \%$ overall yield from the corresponding $N$-acyl thiazolidin-2-thiones $\mathbf{8}$ and $\mathbf{9}$, respectively) with the most efficient methods already described in the literature for the synthesis of these alkaloids in optically pure form..$^{910}$

\section{EXPERIMENTAL}

Reagent grade chemicals were used as purchased except when noticed otherwise. THF was distilled from sodium/benzophenone immediately prior to use. Dichloromethane, diisopropylethylamine and titanium tetrachloride were dried over calcium hydride and 
distilled immediately prior to use. Reactions involving air or water sensitive reagents were carried out in previously flame-dried flasks and under an argon atmosphere.

The reaction progress was followed by TLC on silica gel plates $(0.20 \mathrm{~mm})$ and stained under iodine vapor, potassium permanganate soln. or Dragendorf reagent. Column chromatography separations were performed in silica gel (70-230 and 230-400 Mesh).

The NMR spectra were measured in $\mathrm{CDCl}_{3}$ soln. in a 7.0 Tesla spectrometer at $25{ }^{\circ} \mathrm{C}$. The chemical shifts are reported in part per million downfield from tetramethylsilane $\left({ }^{1} \mathrm{H}-\mathrm{NMR}\right)$ or residual chloroform $\left({ }^{13} \mathrm{C}-\mathrm{NMR}\right)$ and data are reported as follows: chemical shift, integrals, multiplicity ( $\mathrm{s}=$ singlet, $\mathrm{d}=$ doublet, $\mathrm{dd}=$ double dublet, $\mathrm{t}=$ triplet, $\mathrm{q}=$ quartet, $\mathrm{qt}=$ quintuplet, $\mathrm{m}=$ multiplet $), \mathrm{br}$ (broad signal) and coupling constants. Melting points were measured in an open capillary and were not corrected.

$\mathrm{N}$-tert-butoxycarbonyl 2-ethoxy pyrrolidine (5a) and $\mathrm{N}$-tertbutoxycarbonyl 2-methoxy pyrrolidine (5b) were prepared according to the procedure described by Shono and coworkers. ${ }^{19}$ The preparation of $(S)$-3-isopropyl-1,3-thiazolidine-2-thione was carried out according to the procedure by Corre and coworkers. ${ }^{20}$

\section{(S)-4-Benzyl-3-(4-chlorobutanoyl)-1,3-oxazolidin-2-one (3)}

To a soln. of commercially available $(S)$-benzyl-1,3-oxazolidin2-one $(3.0 \mathrm{~g}, 17 \mathrm{mmol})$ in THF $(34 \mathrm{~mL})$ at $-78{ }^{\circ} \mathrm{C}$ was added dropwise a soln. of $n$-BuLi in hexanes (1.96 M, 9.5 mL, $18.6 \mathrm{mmol})$. The reaction mixture was stirred at $-78{ }^{\circ} \mathrm{C}$ for $30 \mathrm{~min}$ and 4 chlorobutanoyl chloride $(2.86 \mathrm{~g}, 20.3 \mathrm{mmol})$. After consumption of the starting material as monitored by TLC, a satd. aq. soln. of $\mathrm{NH}_{4} \mathrm{Cl}(10 \mathrm{~mL})$ was added, the aqueous phase was extracted with ether $(3 \times 10 \mathrm{~mL})$ and the combined organic phase was dried over $\mathrm{MgSO}_{4}$. The crude reaction mixture was purified by silica gel chromatography (10\% EtOAc in hexanes) to afford $(S)-3$ (4.40 g, $15.6 \mathrm{mmol})$ in $92 \%$ yield as a pale yellow oil $\left([\alpha]_{\mathrm{D}}{ }^{20}=+73.0(\mathrm{c} 4.3\right.$, $\mathrm{CH}_{2} \mathrm{Cl}_{2}$ ). IR (neat): 3028, 2964, 2924, 1778, 1693, 1390, 1213 (br), $762,704 \mathrm{~cm}^{-1} ;{ }^{1} \mathrm{H}-\mathrm{NMR}\left(\mathrm{CDCl}_{3}\right): \delta 2.17(\mathrm{qt}, 2 \mathrm{H}, J=6.5 \mathrm{~Hz}), 2.78$ (dd, $1 \mathrm{H}, J=13.3$ and $9.6 \mathrm{~Hz}), 3.12(\mathrm{~m}, 2 \mathrm{H}), 3,27$ (dd, $1 \mathrm{H}, J=13.5$ and 3,3Hz), 3,66 (t, 2H, $J=6.5 \mathrm{~Hz}), 4.20(\mathrm{~m}, 2 \mathrm{H}), 4.68(\mathrm{~m}, 1 \mathrm{H})$, $7.32(\mathrm{~m}, 5 \mathrm{H}) ;{ }^{13} \mathrm{C}-\mathrm{NMR}\left(\mathrm{CDCl}_{3}\right): \delta 26.9,32.7,37.8,44.0,55.1$, $66.3,127.4,128.9,129.4,135.1,153.4,172.1$. Elemental analyses calcd. for $\mathrm{C}_{14} \mathrm{H}_{16} \mathrm{ClNO}_{3}: \% \mathrm{C}-59.68, \% \mathrm{H}-5.72, \% \mathrm{~N}-4.97$. Found: $\% \mathrm{C}-59.70, \% \mathrm{H}-5.68, \% \mathrm{~N}-4.97$.

\section{(S)-4-Benzyl-3-(5-chloropentanoyl)-1,3-oxazolidin-2-one (4)}

The same procedure as described above for $(S)$-3 was employed to provide $(S)-\mathbf{4}$ as a white solid $\left(\mathrm{mp} 66-67^{\circ} \mathrm{C}\right.$, crystals from EtOAchexanes) in $98 \%$ yield. $\left([\alpha]_{\mathrm{D}}{ }^{20}=+63.0\left(c 3.1, \mathrm{CH}_{2} \mathrm{Cl}_{2}\right)\right.$. IR $(\mathrm{KBr})$ : 3028, 2956, 1780, 1699, 1388, 1213 (br), $762 \mathrm{~cm}^{-1}$; ${ }^{1} \mathrm{H}-\mathrm{NMR}$ $\left(\mathrm{CDCl}_{3}\right): \delta 1.86(\mathrm{~m}, 4 \mathrm{H}), 2.77(\mathrm{dd}, 1 \mathrm{H}, J=13.5$ and $9.5 \mathrm{~Hz}), 2.95$ $(\mathrm{m}, 2 \mathrm{H}), 3.29(\mathrm{dd}, 1 \mathrm{H}, J=13.2$ and $3,3 \mathrm{~Hz}), 3,58(\mathrm{~m}, 2 \mathrm{H}), 4.19(\mathrm{~m}$, 2H), $4.68(\mathrm{~m}, 1 \mathrm{H}), 7.31(\mathrm{~m}, 5 \mathrm{H}) ;{ }^{13} \mathrm{C}-\mathrm{NMR}\left(\mathrm{CDCl}_{3}\right): \delta 21.6,31.9$, 34.8, 38.0, 44.7, 55.2, 66.4, 127.6, 129.2, 129.7, 135.5, 153.8, 173.0. HRMS (EI): calcd. for $\mathrm{C}_{15} \mathrm{H}_{18} \mathrm{NO}_{3} \mathrm{Cl}$ : 295.0975. Found: 295.0972.

\section{(S)-4-Isopropyl-3-(4-chlorobutanoyl)-1,3-thiazolidin-2-thione (8)}

A soln. of (S)-4-isopropyl-1,3-thiazolidin-2-thione (1.00 g, 6.20 $\mathrm{mmol})$ in THF $(2 \mathrm{~mL})$ was added to a suspension of $60 \% \mathrm{w} / \mathrm{w} \mathrm{NaH}$ $(0.27 \mathrm{~g}, 6.7 \mathrm{mmol}))$ in THF $(1 \mathrm{~mL})$ at $0{ }^{\circ} \mathrm{C}$. The reaction mixture was stirred $10 \mathrm{~min}$ at $0{ }^{\circ} \mathrm{C}$ and then freshly distilled 4-chlorobutanoyl chloride $(0.958 \mathrm{~g}, 6.82 \mathrm{mmol})$ was added dropwise. The reaction mixture was kept at $0{ }^{\circ} \mathrm{C}$ for $10 \mathrm{~min}$ and then stirred at $\mathrm{rt}$ for $1 \mathrm{~h}$.
After addition of aq. $\mathrm{HCl}(10 \% \mathrm{v} / \mathrm{v}, 5 \mathrm{~mL})$ and extraction with EtOAc $(3 \times 5 \mathrm{~mL})$, the combined organic extracts were washed with brine $(2 \times 5 \mathrm{~mL})$, dried over $\mathrm{Na}_{2} \mathrm{SO}_{4}$ and the solvent was removed under reduced pressure. The crude product was purified by chromatography on silica gel (5\% EtOAc-hexanes) to afford $(S)-8(1.51 \mathrm{~g}, 5.40 \mathrm{mmol})$ in $92 \%$ yield, as a yellow oil. $\left([\alpha]_{\mathrm{D}}{ }^{20}=\right.$ +363.0 (c 2.0, $\mathrm{CHCl}_{3}$ ). IR (neat): 2963, 1696, 1469, 1367, 1276, $750 \mathrm{~cm}^{-1} ;{ }^{1} \mathrm{H}-\mathrm{NMR}\left(\mathrm{CDCl}_{3}\right): \delta 0.97(\mathrm{~d}, 3 \mathrm{H}, J=7.0 \mathrm{~Hz}), 1.07(\mathrm{~d}$, $3 \mathrm{H}, J=7.0 \mathrm{~Hz}), 2.05-2.26(\mathrm{~m}, 2 \mathrm{H}), 2.28-2.44(\mathrm{~m}, 1 \mathrm{H}), 3,03$ (dd, $1 \mathrm{H}, J=11.3$ and $1.1 \mathrm{~Hz}), 3.26-3.37(\mathrm{~m}, 1 \mathrm{H}), 3,59-3.60(\mathrm{~m}, 2 \mathrm{H})$, $3.62(\mathrm{t}, 2 \mathrm{H}, J=6.4 \mathrm{~Hz}), 5.15(\mathrm{ddd}, 1 \mathrm{H}, J=7.7,6.4,1.1 \mathrm{~Hz}) ;{ }^{13} \mathrm{C}-$ $\mathrm{NMR}\left(\mathrm{CDCl}_{3}\right): \delta 17.9,19.2,27.8,30.6,30.9,35.7,44.1,71.6,172.6$, 202.4. HRMS (EI): calcd. for $\mathrm{C}_{10} \mathrm{H}_{16} \mathrm{NOS}_{2} \mathrm{Cl}$ : 265.0362. Found: 265.0365

\section{(S)-4-Isopropyl-3-(5-chloropentanoyl)-1,3-thiazolidin-2- thione (9)}

The same procedure as described above for $(S)-\mathbf{8}$ was employed to provide $(S)-9$ as yellow oil in $96 \%$ yield. $\left([\alpha]_{\mathrm{D}}{ }^{20}=+344.0\right.$ (c 2.0, $\mathrm{CHCl}_{3}$ ). IR (neat): 2962, 1694, 1313, 1259, 1160 (br), $1037 \mathrm{~cm}^{-1}$; ${ }^{1} \mathrm{H}-\mathrm{NMR}\left(\mathrm{CDCl}_{3}\right): \delta 0.97(\mathrm{~d}, 3 \mathrm{H}, J=7.0 \mathrm{~Hz}), 1.06(\mathrm{~d}, 3 \mathrm{H}, J=6.6$ $\mathrm{Hz}), 1.73-1.92(\mathrm{~m} .4 \mathrm{H}), 2.30-2.41(\mathrm{~m}, 1 \mathrm{H}), 3,03$ (dd, $1 \mathrm{H}, J=11.3$ and $0.9 \mathrm{~Hz}), 3.13-3.21(\mathrm{~m}, 1 \mathrm{H}), 3,35-3.45(\mathrm{~m}, 1 \mathrm{H}), 3.49-3.58(\mathrm{~m}$, $3 \mathrm{H}), 5.14-5.19(\mathrm{~m}, 1 \mathrm{H}) ;{ }^{13} \mathrm{C}-\mathrm{NMR}\left(\mathrm{CDCl}_{3}\right): \delta 17.6,18.9,22.1,30.3$, 30.7, 31.7, 37.3, 44.5, 71.4, 173.2, 202.7. HRMS (EI): calcd. for $\mathrm{C}_{11} \mathrm{H}_{18} \mathrm{NOS}_{2} \mathrm{Cl}$ : 279.0518. Found: 279.0517.

tert-Butyl (2R,1'R)-\{2'-oxo-2'-[(4S)-4-benzyl-2-oxo-1,3oxazolan-3-yl]-1' -(2'-chloroethyl)\}-2-ethylazolane-1carboxylate (6)

To a soln. of $\mathrm{TiCl}_{4}(0.12 \mathrm{~mL}, 1.1 \mathrm{mmol})$ in $\mathrm{CH}_{2} \mathrm{Cl}_{2}(2.0 \mathrm{~mL})$ at $-23{ }^{\circ} \mathrm{C}$ was added dropwise a soln. of $(S)-3(0.281 \mathrm{~g}, 1.00 \mathrm{mmol})$ in $\mathrm{CH}_{2} \mathrm{Cl}_{2}(3.0 \mathrm{~mL})$, followed by the addition of diisopropylethylamine $(0.20 \mathrm{~mL}, 1.1 \mathrm{mmol})$. The deep reddish brown mixture obtained was stirred at $-23{ }^{\circ} \mathrm{C}$ for $1 \mathrm{~h}$ and then it was added dropwise a soln. of $\mathrm{N}$-tert-butoxycarbonyl-2-ethoxypyrrolidine (5a, $0.236 \mathrm{~g}, 1.1$ $\mathrm{mmol})$ in $\mathrm{CH}_{2} \mathrm{Cl}_{2}(5 \mathrm{~mL})$. After consumption of the starting material (monitored by TLC), satd. $\mathrm{NH}_{4} \mathrm{Cl}(2.0 \mathrm{~mL})$ was added and the aqueous phase was extracted with $\mathrm{CH}_{2} \mathrm{Cl}_{2}(3 \mathrm{x} 10 \mathrm{~mL})$. The combined organic phase was dried over $\mathrm{MgSO}_{4}$ and the solvent was removed under reduced pressure. The crude product was purified by flash chromatography on silica gel (15\% EtOAchexanes) to provide $6(0.370 \mathrm{~g}, 0.82 \mathrm{mmol})$ in $82 \%$ yield, as a white solid (mp 115.4-116.4 $\left.{ }^{\circ} \mathrm{C}\right) .\left([\alpha]_{\mathrm{D}}^{20}=+51.0\left(\mathrm{c} 1.5, \mathrm{CH}_{2} \mathrm{Cl}_{2}\right)\right.$. IR (KBr): 2970, 1782, 1691, 1445, 1390, 1299, 1207, 1167, 1109, $756 \mathrm{~cm}^{-1} ;{ }^{1} \mathrm{H}-\mathrm{NMR}\left(\mathrm{CDCl}_{3}, 50{ }^{\circ} \mathrm{C}\right): \delta 1.45(\mathrm{~s}, 9 \mathrm{H}), 1.70-2.05(\mathrm{~m}$, $5 \mathrm{H}), 2.25-2.48(\mathrm{~m}, 1 \mathrm{H}), 2.61(\mathrm{dd}, 1 \mathrm{H}, J=10.5$ and $10.3 \mathrm{~Hz}), 3.20-$ $3.35(\mathrm{~m}, 1 \mathrm{H}), 3.35-3.50(\mathrm{~m}, 2 \mathrm{H}), 3.50-3.65(\mathrm{~m}, 2 \mathrm{H}), 4.05-4.20(\mathrm{~m}$, $2 \mathrm{H})$, 4.20-4.40 (m, 1H), 4.40-4.60 (s, 1H, br), 4.60-4.80 (m, 1H), $7.25(\mathrm{~m}, 5 \mathrm{H}) .{ }^{13} \mathrm{C}-\mathrm{NMR}\left(\mathrm{CDCl}_{3}, 50{ }^{\circ} \mathrm{C}\right): \delta 23.7,28.6,28.9,31.0$, 38.3, 43.1, 44.5, 47.4, 55.7, 58.4, 66.2, 80.0, 127.3, 129.0, 129.4, 135.8, 153.0, 155.0, 173.5. HRMS (EI): calcd. for $\mathrm{C}_{18} \mathrm{H}_{22} \mathrm{~N}_{2} \mathrm{O}_{3} \mathrm{Cl}$ $\left(\mathrm{M}^{+/}-\mathrm{C}_{4} \mathrm{H}_{9}: 349.1319\right.$. Found: 349.1317 .

tert-Butyl (2R,1'R)-\{2'-oxo-2'-[(4S)-4-benzyl-2-oxo-1,3oxazolan-3-yl]-1' -(3'-chloropropyl)\}-2-ethylazolane-1carboxylate (7)

The same procedure as described above for (+)-6 afforded (+)7 in $81 \%$ yield, after purification by flash chromatography on silica gel $\left(15 \%\right.$ EtOAc/hexanes) as a pale yellow oil. $\left([\alpha]_{\mathrm{D}}^{20}=+49.6(c\right.$ 
3.6, $\mathrm{CH}_{2} \mathrm{Cl}_{2}$ ). IR (neat): 2974, 1780, 1689, 1483, 1388, 1299, 1205, 1165, 1105, $762 \mathrm{~cm}^{-1}$; ${ }^{1} \mathrm{H}-\mathrm{NMR}\left(\mathrm{CDCl}_{3}, 50{ }^{\circ} \mathrm{C}\right): \delta 1.44(\mathrm{~s}, 9 \mathrm{H})$, $1.20-1.50(\mathrm{~m}, 8 \mathrm{H}), 2.60(\mathrm{dd}, 1 \mathrm{H}, J=13.3$ and $10.4 \mathrm{~Hz}), 3.20-3.40$ (m, 1H), 3.40-3.65 (m, 2H), $3.50(\mathrm{t}, 2 \mathrm{H}, J=6.4 \mathrm{~Hz}), 4.12(\mathrm{~m}, 2 \mathrm{H})$, 4.20-4.35 (s, br, 2H), 4.60-4.80 (s, 1H), 7.29 (m, 5H). ${ }^{13} \mathrm{C}-\mathrm{NMR}$ $\left(\mathrm{CDCl}_{3}, 50{ }^{\circ} \mathrm{C}\right): \delta 21.6,23.6,28.5,28.7,30.7,38.2,44.5,45.7$, 47.1, 55.6, 58.7, 66.1, 79.8, 127.2, 128.9, 129.3, 135.7, 153.1, 154.9, 174.0. HRMS (EI): calcd. for $\mathrm{C}_{19} \mathrm{H}_{24} \mathrm{~N}_{2} \mathrm{O}_{3} \mathrm{Cl}\left(\mathrm{M}^{+/}-\mathrm{C}_{4} \mathrm{H}_{9}\right): 363.1475$. Found: 363.1475.

tert-Butyl (2R,1'R)-\{2'-oxo-2'-[(4S)-4-isopropyl-2-thio-1,3thiazolan-3-yl]-1'-(2'-chloroethyl)\}-2-ethylazolane-1carboxylate (10)

To a soln. of $\mathrm{TiCl}_{4}(0.12 \mathrm{~mL}, 1.1 \mathrm{mmol})$ in $\mathrm{CH}_{2} \mathrm{Cl}_{2}(3.0 \mathrm{~mL})$ at $0{ }^{\circ} \mathrm{C}$ was added a soln. of $(+)-8(0.265 \mathrm{~g}, 1.0 \mathrm{mmol})$ in $\mathrm{CH}_{2} \mathrm{Cl}_{2}$ $(2.0 \mathrm{~mL})$, followed by the addition of diisopropylethylamine $(0.20$ $\mathrm{mL}, 1.1 \mathrm{mmol})$. The redish brown mixture was kept at $0{ }^{\circ} \mathrm{C}$ for 1 $\mathrm{h}$ and then it was cooled to $-23^{\circ} \mathrm{C}$. A previously cooled soln. of 2-methoxy- $N$-tert-butoxycarbonyl pyrrolidine $(\mathbf{5 b}, 0.221 \mathrm{~g}, 1.1$ mmol) was added dropwise and the reaction mixture was stirred for $1 \mathrm{~h}$ at $-23{ }^{\circ} \mathrm{C}$. After addition of satd. soln. of $\mathrm{NH}_{4} \mathrm{Cl}(5.0 \mathrm{~mL})$ and brine $(5.0 \mathrm{~mL})$, the aqueous phase was extracted with $\mathrm{CH}_{2} \mathrm{Cl}_{2}$ $(3 \times 10 \mathrm{~mL})$ and the combined organic phase was dried over $\mathrm{MgSO}_{4}$. After evaporation under reduced pressure, the crude product was purified by chromatography on silica gel (5\% AcOEtHexanes) to afford (+)-10 (0.376 g, $0.80 \mathrm{mmol})$ in $84 \%$ yield as a yellow oil (8.6:1 diastereoisomeric ratio). Data for the major isomer: $\left([\alpha]_{\mathrm{D}}{ }^{20}=+222.0\right.$ (c 1.0, $\left.\mathrm{CHCl}_{3}\right)$. IR (neat): 2969, 1693, 1392, 1366, 1306, 1252, $1166 \mathrm{~cm}^{-1} ;{ }^{1} \mathrm{H}-\mathrm{NMR}\left(\mathrm{CDCl}_{3}, 60{ }^{\circ} \mathrm{C}\right): \delta$ $0.98(\mathrm{~d}, 3 \mathrm{H}, J=7.0 \mathrm{~Hz}), 1.08(\mathrm{~d}, 3 \mathrm{H}, J=7.0 \mathrm{~Hz}), 1.47(\mathrm{~s}, 9 \mathrm{H})$, $1.72-2.01(\mathrm{~m} .5 \mathrm{H}), 2.09-2.38(\mathrm{~m}, 2 \mathrm{H}), 3,03(\mathrm{dd}, 1 \mathrm{H}, J=11.5$ and $1.3 \mathrm{~Hz}), 3.15-3.30(\mathrm{~m}, 1 \mathrm{H}), 3.4-3.6(\mathrm{~m}, 4 \mathrm{H}), 4.38(\mathrm{~m}, 1 \mathrm{H}), 4,92-$ $5.00(\mathrm{~m}, 1 \mathrm{H}), 5.11-5.18(\mathrm{~m}, 1 \mathrm{H}) ;{ }^{13} \mathrm{C}-\mathrm{NMR}\left(\mathrm{CDCl}_{3}\right): \delta 17.3,19.0$, 23.8, 28.3, 28.5, 30.3, 31.1, 31.5, 43.0, 44.7, 47.4, 58.0, 71.8, 79.7, 154.6, 174.0, 202.0. HRMS (EI): calcd. for $\mathrm{C}_{19} \mathrm{H}_{31} \mathrm{~N}_{2} \mathrm{O}_{3} \mathrm{~S}_{2} \mathrm{Cl}$ : 434.1465. Found: 434.1462.

tert-Butyl (2R,1'R)-\{2'-oxo-2'-[(4S)-4-isopropyl-2-thio-1,3thiazolan-3-yl]-1'-(3'-chloropropyl)\}-2-ethylazolane-1carboxylate (11)

The same procedure as described for (+)-10 was employed to afford (+)-11 in 84\% yield, after chromatography on silica gel (5\% EtOAc-hexanes), as a yellow oil (10:1 diastereoisomeric ratio). Data for the major isomer: $\left([\alpha]_{\mathrm{D}}{ }^{20}=+248.0\left(c 2.0, \mathrm{CHCl}_{3}\right)\right.$. IR (neat): 2967, 1693, 1392, 1366, 1306, 1253, $1166 \mathrm{~cm}^{-1} ;{ }^{1} \mathrm{H}-\mathrm{NMR}\left(\mathrm{CDCl}_{3}\right.$, $\left.60{ }^{\circ} \mathrm{C}\right): \delta 0.95(\mathrm{~d}, 3 \mathrm{H}, J=7.0 \mathrm{~Hz}), 1.06(, 3 \mathrm{H}, J=7.0 \mathrm{~Hz}), 1.47(\mathrm{~s}$, $9 \mathrm{H}), 1.61-2.00$ (m. 8H), 2.27-2.38 (m, 1H), 2.98-3,02 (m, 1H), 3.19$3.39(\mathrm{~m}, 1 \mathrm{H}), 3.42-3.53(\mathrm{~m}, 4 \mathrm{H}), 4,9-4.94(\mathrm{~m}, 1 \mathrm{H}), 5.08-5.19(\mathrm{~m}$, $2 \mathrm{H}) ;{ }^{13} \mathrm{C}-\mathrm{NMR}\left(\mathrm{CDCl}_{3}\right): \delta 17.4,19.2,23.9,26.5,28.4,28.7,30.0$, 30.7, 31.1, 44.7, 46.0, 47.3, 58.4, 72.0, 79.7, 154.7, 174.9, 202.2. HRMS (EI): calcd. for $\mathrm{C}_{20} \mathrm{H}_{33} \mathrm{~N}_{2} \mathrm{O}_{3} \mathrm{~S}_{2} \mathrm{Cl}$ : 448.1621. Found: 448.1611.

\section{(+)-Isoretronecanol (1)}

To a soln. of $(+)-10(0.146 \mathrm{~g}, 0.32 \mathrm{mmol})$ in THF $(2.0 \mathrm{~mL})$ at $0{ }^{\circ} \mathrm{C}$ was added methanol $(0.02 \mathrm{~mL})$, followed by the addition of a soln. of $\mathrm{LiBH}_{4}(0.023 \mathrm{~g}, 1.18 \mathrm{mmol})$ in THF $(2.0 \mathrm{~mL})$. The mixture was stirred $1 \mathrm{~h}$ at $0{ }^{\circ} \mathrm{C}$ and a satd. soln. of $\mathrm{NH}_{4} \mathrm{Cl}(5.0$ $\mathrm{mL})$ was added and extracted with ether $(3 \times 5.0 \mathrm{~mL})$. The organic phase was dried over $\mathrm{MgSO}_{4}$, the solvent was evaporated under reduced pressure to provide a crude mixture of alcohol $\mathbf{1 2}$ and
(S)-4-isopropyl-1,3-thiazolidin-2-thione ( $0.130 \mathrm{~g})$ which was taken up in $\mathrm{CH}_{2} \mathrm{Cl}_{2}(12.0 \mathrm{~mL})$ and added to a mixture of trifluoroacetic acid $(0.27 \mathrm{~mL}, 3.5 \mathrm{mmol})$ containing triethylsilane $(0.050 \mathrm{~mL}$, $0.30 \mathrm{mmol}$ ) at $0{ }^{\circ} \mathrm{C}$. The reaction mixture was stirred at $\mathrm{rt}$ for 24 $\mathrm{h}$ and it was quenched by the addition of satd. aq. $\mathrm{NaHCO}_{3}(2.0$ $\mathrm{mL}$ ) and excess solid $\mathrm{NaHCO}_{3}$ to reach $\mathrm{pH}$ 9.0. The reaction mixture was vigorously stirred at $\mathrm{rt}$ for $16 \mathrm{~h}$, filtered to separate the solids and the phases were separated. The organic phase was dried over $\mathrm{MgSO}_{4}$ and after removal of the solvent under reduced pressure, the crude reaction mixture was purified by column chromatography on neutral alumina: elution with $\mathrm{CH}_{2} \mathrm{Cl}_{2}$ provided (S)-4-isopropyl-1,3-thiazolidin-2-thione $(0.034 \mathrm{~g}, 0.21 \mathrm{mmol})$ in $66 \%$ yield and elution with $10 \% \mathrm{MeOH} / \mathrm{CHCl}_{3}$ provided (+)isoretronecanol (1) in $43 \%$ yield $(0.019 \mathrm{~g}, 0.14 \mathrm{mmol})$ as a pale yellow oil. $[\alpha]_{\mathrm{D}}{ }^{20}=+71.0(c$ 1.3, EtOH $)$; lit. ${ }^{21}:[\alpha]_{\mathrm{D}}{ }^{20}=+71.7(c$ 1.0, EtOH). IR (neat): 3384, 2954, 2870, 1454, 1216, 1107, 1072, 1032, $771 \mathrm{~cm}^{-1} ;{ }^{1} \mathrm{H}-\mathrm{NMR}\left(\mathrm{CDCl}_{3}\right): \delta 1.30-1.45(\mathrm{~m}, 1 \mathrm{H}), 1.45-$ $1.60(\mathrm{~m}, 1 \mathrm{H}), 1.4-2.0(\mathrm{~m}, 4 \mathrm{H}), 2.35-2.60(\mathrm{~m}, 2 \mathrm{H}), 2.62(\mathrm{~s}, 1 \mathrm{H}$, br), $3.02(\mathrm{~s}, 1 \mathrm{H}, \mathrm{br}), 3,20(\mathrm{~s}, 1 \mathrm{H}, \mathrm{br}), 3 . .52(\mathrm{~s}, 1 \mathrm{H}, \mathrm{br}), 3.5-3.7(\mathrm{~m}$, $2 \mathrm{H}), 3,90(\mathrm{~s}, 1 \mathrm{H}, \mathrm{br}) ;{ }^{13} \mathrm{C}-\mathrm{NMR}\left(\mathrm{CDCl}_{3}\right): \delta 25.9,26.5,27.2,44.2$, 54.0, 55.6, 63.1, 66.4 (Literature data ${ }^{18}: \delta$ 25.9, 26.6, 27.3, 43.9, 54.0, 55.6, 63.3, 66.8). HRMS (EI): calcd. for $\mathrm{C}_{8} \mathrm{H}_{15} \mathrm{NO}: 141.1154$. Found: 141.1154.

\section{(+)-5-epi-Tashiromine (2)}

To a soln. of (+)-11 $(0.059 \mathrm{~g}, 0.13 \mathrm{mmol})$ in THF $(2.0 \mathrm{~mL})$ at 0 ${ }^{\circ} \mathrm{C}$ was added methanol $(0.02 \mathrm{~mL})$, followed by the addition of a soln. of $\mathrm{LiBH}_{4}(0.010 \mathrm{~g}, 0.50 \mathrm{mmol})$ in THF $(2.0 \mathrm{~mL})$. The mixture was stirred $1 \mathrm{~h}$ at $0{ }^{\circ} \mathrm{C}$ and a satd. soln. of $\mathrm{NH}_{4} \mathrm{Cl}(5.0 \mathrm{~mL})$ was added and extracted with ether $(3 \times 5.0 \mathrm{~mL})$. The organic phase was dried over $\mathrm{MgSO}_{4}$, the solvent was evaporated under reduced pressure to provide a crude mixture of alcohol 13 and $(S)$-4isopropyl-1,3-thiazolidin-2-thione which was taken up in $\mathrm{CH}_{2} \mathrm{Cl}_{2}$ $(12.0 \mathrm{~mL})$ and added to a mixture of trifluoroacetic acid $(0.17 \mathrm{~mL}$, $2.2 \mathrm{mmol})$ containing triethylsilane $(0.030 \mathrm{~mL}, 0.30 \mathrm{mmol})$ at 0 ${ }^{\circ} \mathrm{C}$. The reaction mixture was stirred at $\mathrm{rt}$ for $24 \mathrm{~h}$ and it was quenched by the addition of satd. aq. $\mathrm{NaHCO}_{3}(2.0 \mathrm{~mL})$ and excess solid $\mathrm{NaHCO}_{3}$ to reach $\mathrm{pH} 9.0$. The reaction mixture was vigorously stirred at $\mathrm{rt}$ for $16 \mathrm{~h}$, filtered to separate the solids and the phases were separated. The organic phase was dried over $\mathrm{MgSO}_{4}$ and after removal of the solvent under reduced pressure, the crude reaction mixture was purified by column chromatography on neutral alumina: elution with $\mathrm{CH}_{2} \mathrm{Cl}_{2}$ provided $(S)$-4-isopropyl-1,3thiazolidin-2-thione $(0.015 \mathrm{~g}, 0.09 \mathrm{mmol})$ in $70 \%$ yield and elution with $10 \% \mathrm{MeOH} / \mathrm{CHCl}_{3}$ provided (+)-5-epi-tashiromine (2) in $49 \%$ yield $(0.010 \mathrm{~g}, 0.14 \mathrm{mmol})$ as a pale yellow oil. $[\alpha]_{\mathrm{D}}{ }^{20}=+15.0(\mathrm{c}$ 1.3, EtOH). (+)-5-epi-tashiromine. $\mathrm{HCl}:[\alpha]_{\mathrm{D}}{ }^{20}=+28.0(c 0.45$, EtOH); liter. lit. ${ }^{10}:[\alpha]_{\mathrm{D}}{ }^{20}=+29.1$ (c 0.45, EtOH). IR (neat): 3109 , $3018,1645,1396,1250,1074,1041 \mathrm{~cm}^{-1}$; ${ }^{1} \mathrm{H}-\mathrm{NMR}\left(\mathrm{CDCl}_{3}\right): \delta 1.25-$ $1.91(\mathrm{~m}, 9 \mathrm{H}), 1.92-2.08(\mathrm{~m}, 3 \mathrm{H}), 2.45(\mathrm{~s}, \mathrm{br}, 1 \mathrm{H}), 3.02-3.06(\mathrm{~m}$, $2 \mathrm{H}), 3.72(\mathrm{~d}, 1 \mathrm{H}, J=10.7 \mathrm{~Hz}), 4.12-4 ; 13(\mathrm{~m}, 1 \mathrm{H}) ;{ }^{13} \mathrm{C}-\mathrm{NMR}\left(\mathrm{CDCl}_{3}\right)$ : $\delta$ 20.6, 23.1, 25.2, 29.7, 35.5, 52.9, 54.3, 65.4, 66.4 (Literature data $\left.^{10}: \delta 20.7,23.2,25.6,29.7,35.3,53.2,54.4,65.6,66.7\right)$. HRMS (EI): calcd. for $\mathrm{C}_{8} \mathrm{H}_{15} \mathrm{NO}$ : 141.1154. Found: 141.1154.

\section{ACKNOWLEDGMENTS}

The authors would like to thank FAPESP (Fundação de Amparo à Pesquisa no Estado de São Paulo) for financial support and fellowship and CNPq (Conselho Nacional de Desenvolvimento Científico e Tecnológico) for research fellowship. 


\section{REFERENCES AND NOTES}

1. Fu, P. P.; Wia, Q. S.; Lin, G.; Chou, M. W.; Drug Metabolism Rev. 2004, 36,1 .

2. For a recent review on indolizidine and quinolizidine alkaloids, see: Michael, J. P.; Nat. Prod. Rep. 2007, 24, 191.

3. For recent reviews on the chemistry of $\mathrm{N}$-acyliminium ions, see: Speckamp, W. N.; Moolenaar, M. J.; Tetrahedron 2000, 56, 3817; Pilli, R. A.; Rosso, G. B. In Science of Synthesis. Houben-Weyl Methods of Molecular Transformations; Padwa, A., ed.; Stuttgart: Thieme, 2004, vol. 27, p. $375-$ 440.

4. Pilli, R. A.; Dias, L. C.; Maldaner, A. O.; J. Org. Chem. 1995, 60, 717; Pilli, R. A.; Russowsky, D.; J. Org. Chem. 1996, 61, 3187; Pilli, R. A.; Santos, L. S.; Tetrahedron Lett. 2001, 42, 6999; Pilli, R. A.; Zanotto, P. R.; Böckelmann, M. A.; Tetrahedron Lett. 2001, 42, 7003; Klitzke, C. F.; Pilli, R. A.; Tetrahedron Lett. 2001, 42, 5605; Santos, L. S.; Pilli, R. A.; J. Braz. Chem. Soc. 2003, 14, 982.

5. Fuentes, L. M.; Shinkai, I.; Salzmann, T. N.; J. Am.Chem. Soc. 1986, 108, 4675.

6. Nagao, Y.; Kumagai, T.; Tamai, S.; Abe, T.; Kuramoto, Y.; Taga, T.; Aoyagi, S.; Nagase, Y.; Ochiai, M.; Inoue, Y.; Fujita, E.; J. Am. Chem. Soc. 1986, 108, 4673; Nagao, Y.; Dai, W-M.; Ochiai, M.; Tsukagoshi, S.; Fujita, E.; J. Am. Chem. Soc. 1988, 110, 289; Nagao, Y.; Daí, W-M.; Ochiai, M.; Tsukagoshi, S.; Fujita, E.; J. Org. Chem. 1990, 55, 1148.

7. Nagao, Y.; Daí, W-M.; Ochiai, M.; Tetrahedron Lett. 1988, 29, 6133; Nagao, Y.; Daí, W-M.; Ochiai, M.; Shiro, M.; Tetrahedron 1990, 46, 6361.

8. Pilli, R. A.; Alves, C. F.; Böckelmann, M. A.; Mascarenhas, Y. P.; Nery, J. G.; Vencato, I.; Tetrahedron Lett. 1999, 40, 2891; Pilli, R. A.; Böckelmann, M. A.; Alves, C. F.; J. Braz. Chem. Soc. 2001, 12, 634.

9. For recent syntheses of (+)- and (-)-isoretronecanol, see: Bertrand, S.; Hoffmann, N.; Pete, J-P.; Eur. J. Org. Chem. 2000, 2227; Ledoux, S.
Machalant, E.; Celerier, J-P.; Lhommet, G.; Tetrahedron Lett. 2001, 42, 5397; Dieter, R. K.; Chen, N.; Watson, R. T.; Tetrahedron 2005, 61, 3221.

10. Ha, D-C.; Park, S-H.; Choi, K-S.; Yun, C-S.; Bull. Kor. Chem. Soc. 1998, 19, 728; Banwell, M. G.; Beck, D. A. S.; Smith, J. A.; Org. Biomol. 2004, 2, 157; Gage, J. L.; Branchard, B. P.; Tetrahedron Lett. 1997, 28, 7007; Agami, C.; Dechoux, L.; Hebbe, S.; Ménard, C.; Tetrahedron 2004, 60, 5433; Dieter, R. K.; Chen, N.; Watson, R. T.; Tetrahedron 2005, 61, 3221.

11. Pereira, E.; Alves, C. F.; Böckelmann, M. A.; Pilli, R. A.; Tetrahedron Lett. 2005, 46, 2691.

12. Ohmiya, S.; Kubo, H.; Otomasu, H.; Saito, K.; Murakoshi, I.; Heterocycles 1999, 30, 537.

13. Asres, K.; Sporer, F.; Wink, M.; Biochem. Syst. Ecol. 2004, 32, 915.

14. Alves, C. F.; PhD Thesis, State University of Campinas, 1998.

15. Damon, R. E.; Coppola, G. M.; Tetrahedron Lett. 1990, 31, 2849; Evans, D. A.; Black, W. C.; J. Am. Chem. Soc. 1993, 115, 4497; Evans, D. A.; Johnson, J. S.; J. Org. Chem. 1997, 62, 786; Evans, D. A.; Wu, L. D.; Wiener, J. J. M.; Johnson, J. S.; Ripin, D. H. B.; Tedrow, J. S.; J. Org. Chem. 1999, 64, 6411.

16. Nagao, Y.; Yagi, M.; Ikede, T.; Fujita, E.; Tetrahedron Lett. 1982, 23, 201; Crimmins, M. T.; King, B. W.; Tabet, E. A.; J. Am. Chem. Soc. 1997, 119, 7883; Crimmins, M. T.; King, B. W.; Tabet, E. A.; Chaudhary, K.; J. Org. Chem. 2001, 66, 894.

17. HPLC analyses on the crude mixtures of adducts $\mathbf{1 0}$ and $\mathbf{1 1}$ were carried out with Hypersil column $(5 \mu \mathrm{m}, 200 \times 4.6 \mathrm{~mm})$ and $5 \%$ hexanesisopropanol (v/v) mixture as the eluent.

18. David, O.; Blot, J.; Bellec, C.; Fargeau-Bellassoued, M-C.; Haviari, G.; Célérier, J-P.; Lhommet, G.; Gramain, J-C.; Gardette, D.; J. Org. Chem. 1999, 64, 3122.

19. Shono, T.; Matsumura, Y.; Tsubata, K.; Org. Synth. 1985, 63, 206.

20. Corre, M. L.; Toupet, L.; Delaunay, D.; J. Org. Chem. 1995, 60, 6604.

21. Robins, D. J.; Sakdarat, S.; Chem. Commun. 1979, 1181 